\title{
ARMANDO Development through Capitalism: the only game in town
}

\author{
Dani Rodrik, One Economics Many Recipes: Globalization, \\ Institutions and Economic Growth, \\ Princeton, Princeton University Press, 2007.
}

The central message of this book is the following: developing countries are in strong need of economic growth or expansion. There is only one way to achieve such growth: properly working markets, strong property rights and gradual and careful integration in the world economy. However, there are many ways to set in place the conditions which make such growth possible, that is, the conditions which make markets work, property rights prevail and integration in the world economy successful. Hence, the title of the book: One Economics Many Recipes.

The road to economic growth begins, according to Rodrik, when countries identify the most pressing growth constraints that affect them and solve them utilizing policy tools suited to their own needs, that is, based on their own conditions and capabilities (Chapters 2 and 3 provide details as to how to diagnose the constraints and what polices can be used to tackle them). This implies that 'one-size fits all' approaches are a bad idea. For instance, the 'recipe' for economic growth attached to the Washington Consensus is doomed to fail most of the times it is applied, if not all, as it constitutes, precisely, a 'one size fits all' strategy. Once growth constraints have been dealt with and economic expansion achieved, countries must make sure it will go on. This calls for the introduction of what Rodrik terms 'institutions for high-quality growth'. These are institutions which guarantee control over private property, regulate or 'steer' markets (for instance, banking regulations), provide macroeconomic stability (for example, Central Banks), supply social insurance (unemployment benefits and the like) and allow for the successful management of social conflicts (high-quality judiciary, rule of law, representative political institutions, and so forth).

All of the above is not enough, however, for developing countries to improve their condition, as the current global order does not favour them - it actually undermines them. So, if we are serious about development - as a matter of fact, if we are serious about constructing a better world for everybody - this order must change. Rodrik proposes that, in the short term, all countries aim for economic harmonization and more integration, but allowing for exit or 'escape' clauses to be used when such integration jeopardizes the economic interest of any given 
nation. In the long term, humanity should build a global federal system, similar to the federalism currently prevailing in the United States. In other words, Rodrik is calling for a world government which will manage what eventually will become a truly worldwide market (today's global economy is far from being fully integrated).

The book constitutes a breath of fresh air in the field of economic growth. This is because it departs from orthodox economic analysis. There is no use of econometrics, only a bit of mathematics, a lot of common sense, as well as much comparative political economy - an essential ingredient when we are trying to understand why some economies thrive and how less successful economies could improve their performance. In this respect, as Rodrik himself acknowledges, his work 'harks back to an earlier generation of studies,' such as Albert O. Hirschman's The Strategy of Economic Development (1958), Alexander Gerschenkron's Economic Backwardness in Historical Perspective (1962), and W. W. Rostow's The Stages of Economic Growth (1965), which are all now considered as major and classical contributions in political economy.

Given his flexible approach, Rodrik not only departs from orthodox economic analysis; he also moves away from the typical economic 'prescriptions' and 'recipes' for achieving economic prosperity. For instance, he argues that property rights are crucial for economic growth, as most serious political economists do, however, he denies that such rights have to be embodied in institutions such as those found in the West, at least not in the beginning of the growth process (later on things are different as, eventually, property rights will need to be protected by Western-style independent courts and representative authorities). Thus, in the early stages of growth there is no need for any nation to 'look' like advanced countries. For instance, in China there are no property rights as they are understood in developed nations but, as Rodrik highlights, people can control property and, most importantly, the product of property. This has been achieved not through independent courts and representative authorities but, rather, through associations at the community level in the form of Township and Village Enterprises, which have contributed significantly to China's relatively recent economic success.

Just like China, other countries (especially Taiwan, Vietnam, Mauritius, South Korea and India, which are the ones most mentioned by Rodrik when illustrating his points) have managed to get their economies going by not relying on orthodox recommendations. For example, whereas an average Western economist would consider free trade a good idea (in theory, it allocates resources efficiently and buttresses economic growth), the countries already mentioned were very careful when deciding when and how to open their economies to international 
competition. This helped them enormously and provided them with production possibilities not known in, for instance, Latin America, a region where free trade was embraced rapidly.

With regard to Latin America, it must be said that Rodrik's criticisms of orthodox thinking are somewhat inaccurate. He argues that the policy recommendations of the World Bank (WB) and the International Monetary Fund (IMF), applied in Latin countries during the 1980 os and 1990s, have not paid off, which is why the region has experienced low economic growth rates in the last three decades. While this is true, Rodrik forgets that at the beginning of the 1980s Latin America sunk into the debt crisis, which was a result of irresponsible government behaviour on the part of Mexico and other nations who simply got in debt well beyond their ability to pay. The IMF and the WB had nothing to do with it (of course, the debt crisis was also the responsibility of the international private banks that continued to lend money to Latin countries). The debt crisis translated into terrible balance of payment difficulties, as well as losses of per capita income which, in some cases, meant that countries lost years of economic progress. Also, all affected countries stopped investing in infrastructure and social programmes. In short, as a result of the crisis, Latin nations had to embark on adjustment, rather than growth, programmes. This happened following the recommendations of the IMF and the WB certainly, but it was unavoidable, with or without such recommendations as what these nations required was to restore balance of payments equilibrium and generate enough foreign currency to cover their international obligations. So, the IMF and the WB cannot be blamed, at least not fully, for the pathetic economic performance of Latin America in the 1980s. With regard to the 1990s, again, the lack of economic growth was not the responsibility of either the IMF or the WB. For instance, Mexico fell into a major financial crisis in 1994 (a crisis generated by political factors endemic to the country and by economic policy mistakes), which affected the entire region. Nor was it the fault of the IMF or the WB that Argentina, having gone for a currency board which, by definition, limited its borrowing capacity, got into debt again, especially at the province or local levels, a situation which helps us in understanding the collapse of this board and the disgraceful economic performance of Argentina in subsequent years.

This does not constitute a defence of the WB and the IMF. Actually, Rodrik's main point is sound: the recommendations of both institutions are usually not tailored for each case they deal with, which is why they tend to fail. My point is that it is not accurate to say that whatever happens inside countries is the responsibility of foreign bodies only; the politicians, citizens, businessmen, governments etc. of any country always bear some responsibility for what happens in their land. Also, let us not forget that, when Latin America experienced relatively high rates of growth 
(1950s-1970s), the region did not manage to leave poverty and inequality behind. IMF or no IMF, WB or no WB, Latin countries have simply been incapable of sorting their societies out. Even Chile, one of the most successful Latin American countries, still suffers from poverty and inequality. In addition, let us not forget that Mexico and Brazil are two of the countries of the world which show some of the worst income and wealth distributions: are we to blame the IMF and the WB for this?

As I said, Rodrik is right to argue that orthodox thinking is wrong when it calls for the same policies for every case. Yet he is also correct in regarding the core ideas of orthodox thinking as actually right. It is true, as orthodox economic theory claims, that economic growth requires macroeconomic stability, access to international markets, investments in human capital, technological innovation or at least the ability to adapt to innovations, savings, financial institutions, properly working markets and the protection of property rights at all levels. However, one must insist, as Rodrik does, that there are many ways to achieve macroeconomic stability, access to international markets, the protection of property rights and so on. Let us put it this way, there is one way and only one way to achieve economic prosperity: being like the West. This means that countries wishing to have successful economies have to adhere to the capitalist system of production but, obviously, they must do it following their own culture, traditions, politics, needs, conditions, capabilities and so forth. So, One Economics Many Recipes actually means Capitalism Many Ways.

When they speak about economic phenomena, most economists, sociologists, political scientists, politicians, journalists and ordinary people do not use the term 'capitalism', and instead simply say 'the economy'. However, it is evident that 'the economy' is the capitalist economy, whether this is acknowledged or not. Rodrik does speak of capitalism, although most of the time he seems to be talking about 'an economy' which, it turns out, is capitalism. This is relevant because, nowadays, many economists and political economists take it for granted that capitalism is 'the economy' or, put the other way round, 'the economy' is capitalism. In so doing, they miss a crucial point: out of all the possible economic systems, only capitalism has proven to work in the long-term. Rodrik's book does make this important point, although not explicitly. Indeed, it seems to me that what Rodrik means to say is that societies which are economically successful are 'capitalism-capable societies'. This means that they have managed to put capitalism in place or, at least, economic structures which reproduce the economic incentives associated with it. ${ }^{1}$ Besides setting capitalism in place, capitalism-capable societies fine-

1. Armando Román-Zozaya, 'Development as the capitalism-capable society', paper prepared for delivery at The 2009 Congress of the Latin American Studies Association, Rio de Janeiro, Brazil, June, 2009. Available at <http://lasa. international.pitt.edu/members/congress-papers/lasa2009/files/RomanZozayaArmando.pdf> 
tune it whenever necessary and, of course, manage to make it work for most of their people (social policy has been crucial in these regards). From this it follows, although Rodrik does not explain it in these words, that countries which are not capitalism-capable are the ones whose economies struggle.

So, the message embodied in Rodrik's book is clear: Development is only possible through capitalism; and the capitalist system of production is the only game in town. However, the message is not complete. For capitalism to work, strong states are required. ${ }^{2}$ As a matter of fact, there is not a single country in the world considered to be economically successful which does not count on a strong state - that is, a reliable government and a sense of citizenship (the identification of all, or most, individuals with each other as members of the same polity, and with their government). Rodrik does not make this important point which, in my view, is crucial in understanding why some countries do better than others in terms of economic performance. For instance, Latin America is full of weak states and of weak economies. The same goes for Africa, where the situation is even worse. Is this nothing but a coincidence?

Of course, whether stating it in Rodrik's words or mine, the claim according to which capitalism is the only game in town will encounter strong criticisms, especially in the development literature ${ }^{3}$ and, particularly, from those who study development through the lenses of anthropology. The latter are very likely to argue that Rodrik, and myself, do not understand that indigenous people do not like capitalism or, worse, that the capitalist system only results in such people being economically hindered. We can also expect harsh criticisms from students of development and feminism, development and Marxism, and development and the environment, at least. In response, let me say that capitalism does not have to harm indigenous people, women, particular social classes nor the environment. It only does so when not regulated, when it is assumed that markets take care of everything. Neither Rodrik, nor I, are calling for such a capitalism.

Now, let us turn to some of the doors the book leaves open. Rodrik argues that growth constraints can be of various types, one of them being taxes. For instance, a tax on savings may hamper savings and, therefore, limit investment possibilities. As a matter of fact, Rodrik refers to taxes as 'distortions' which harm the economy. In my view, it is not fair to consider taxes as 'distortions' without

2. See ibid.

3. The development literature is not the same as the economic growth one. The former focuses on economic, political, cultural and social issues and problems experienced by the poorer people of Africa, Latin America and Asia. The latter concentrates on understanding how economies in general (poor or rich) expand or grow, that is to say, how employment, investment, savings, technological change, education and government action interact to produce larger, more complex, richer and more prosperous economic systems. Obviously, although they are not the same, both sets of literature are clearly related to each other. 
taking into account what they are used for. For example, Rodrik himself holds that the economy requires regulatory bodies, policing, enforcement of contracts and so forth. All of these have to be financed somehow, that is, by taxes. So, are all taxes really 'distortions'? The same goes for social insurance and a high-quality judiciary, both of which, according to Rodrik, are essential for long-term economic growth: are the taxes which back them also to be considered 'distortions'?

It is important to stress that, except for India and Mauritius, the countries used by Rodrik as examples to illustrate his arguments are not democratic. For instance, he regularly mentions China as a paradigmatic case of economic success. Likewise, South Korea and Taiwan were not democracies when their economies took off. He also focuses on Vietnam, which is far from being a democracy. Indeed, even regarding India, it is possible to argue that it is not a fully-working democracy: discrimination on the basis of caste and sex, at least, is endemic. In serious democracies, although discrimination has not been totally done away with, it is not as prevalent. So, the obvious question is the following: do developing countries have to be non-democratic to achieve economic success? Rodrik argues that democracy is a 'metainstitution' as it allows societies to decide which institutions or rules of social interaction are the ones to prevail. So, regarding economic prosperity, democracy is essential as through it there will be representative governments which, in theory and in fact, protect individual liberties and, therefore, allow for economies to work better. To support his argument, Rodrik presents figures, according to which democracies show more consistency with regard to economic growth than authoritarian countries in the long-term. All this is very well, but the matter of economic prosperity and authoritarianism is not, in my view, successfully dealt with in this book. Rodrik says that in the long-term democracies are economically superior, but what about the short-term? How is it that most of the countries which in the last four decades have managed to get their economies going are not democratic? What should we think, for instance, of China? Are we to ignore the nature of its political system and, above all, the consequences of such a system for Chinese people only because, from the economic point of view, China has delivered? Rodrik's book does not provide us with answers for questions like this one. This is not surprising as we are dealing with very complex and difficult issues which, once they are being discussed, generate even more dubts and, of course, questions.

Finally, Rodrik argues that the world economy, although more integrated than ever, is still far from being a truly global market. In fact, the mere existence of nation-states results in the segmentation of all markets and, in turn, undermines economic efficiency and world-wide growth. So, in the short-term, the world economy must amalgamate more, but, as already explained, allowing for countries 
to use 'escape' clauses if necessary. In the long-term, there should be a world government regulating the world economy, which, by then, will be fully integrated. All this makes sense. Indeed, today's advanced countries built their economies gradually, relying on a fair amount of protectionism. Only after they reached a certain degree of prosperity were they in a position to embrace more and more free trade in more and more areas, something Rodrik himself acknowledges. A similar point was made a long time ago in a book based on the economic experience of the United States and some European nations: Friedrich List's National System of Political Economy, published in German in 1841. List argued that countries need to have space to build their economies before going for free trade. It was following this 'recipe' that the US and Germany managed to become the economic powers they were by the 1900s. This is also how the East Asian nations built their economies during the second half of the 2oth century. Actually, List's book figured among the favourites of many East Asian policy makers of the 1950s and 1960s. So, what Rodrik wants is for developing countries to do exactly what successful countries did at some point of their economic evolution. However, he does not shed much light on how his proposed system will work. For instance, he says that any country using 'escape' clauses must 'pay' to compensate the nations affected by its decision. Who should the payment be made to? To the proposed world government? Also, who is to determine the amount to be paid? In addition, he speaks of a 'world government' which has to be democratically elected but 'with due regard to the pre-eminence of the economically more powerful countries'. What exactly does that mean? Can democracy work if it allows certain actors 'pre-eminence' over others? Again, these are very difficult questions and Rodrik should not be blamed for not answering them. Indeed, let us be glad that someone of Rodrik's academic stature and reputation is encouraging us to jettison onesize-fits-all models, expanding our appreciation of the conditions of what I call 'capitalism-capable societies' and leading us to consider more carefully what is required to build a better world.

Armando Román-Zozaya

Economics Faculty,

Universidad Anáhuac México Norte, México

\section{the globaljusticenetwork}

